\title{
CONVERSATIONS
}

Article received on February $23^{\text {rd }} 2017$

Article accepted on March $10^{\text {th }} 2017$

UDC: 7.072.2:929 Шуваковић М.(047.53)

\author{
Aleš Erjavec* \\ ZRC SAZU, Institute of Philosophy, Ljubljana \\ University of Ljubljana
}

\section{AN INTERVIEW WITH PROF. DR. MIŠKO ŠUVAKOVIĆ}

Prof. Dr. Miško Šuvaković obtained his $\mathrm{PhD}$ at the Faculty of Fine Arts of the University of Arts in Belgrade, in 1993. He was Professor of Applied Aesthetics at the Faculty of Music in Belgrade (1996-2015). Currently, he is Professor of Applied Aesthetics \& Theory of Art and Media at the Faculty of Media and Communications in Belgrade. He is also Dean of the Faculty of Media and Communications in Belgrade. He is a member of the Slovenian Society of Aesthetics. He is the president of the Society for Aesthetics of Architecture and Visual Arts of Serbia and is also Second Vice-president of the International Association for Aesthetics (IAA).

He was a member of the conceptualist Group 143 (1975-1980), a member of the informal theoretical community "The Community for Researching Space" (19821989) and member of the theoretical-performing organisation "Walking Theory" (since 2000), as well as a follower of the new media and performance artistic and designer platform PSE (Provisional Salta Ensemble, since 2008).

He edited the magazine Katalog 143 [Catalogue 143, 1976-1978] and the independent theoretical magazine Mentalni prostor [Mental Space, Belgrade, 1982-1987]. He has been a member of the editorial staffs of TransKatalog [TransCatalogue, Novi Sad, 1995-1998], the magazine Teorija koja hoda [Walking Theory, Belgrade, since 2001], Razlika [Difference, Tuzla, 2002], Sarajevske sveske [Sarajevo Notebooks, Sarajevo, 2005] and $A M$ [Art Media, Belgrade, 2012].

* Author contact information: ales.erjavec@zrc-sazu.si 
He has published or edited $\mathbf{5 0}$ books and numerous essays in Serbian, Slovenian, Croatian, Macedonian, Bosnian, English, German, French, Armenian, Belorussian, Chinese, etc.

Would you agree if I were to professionally describe you as an aesthetician and theorist of art and culture?

I try to avoid identifying myself, whether in professional, racial, ethnic, or cultural terms, etc. Over the course of my long life, I have gone through several professions - I was a conceptual artist, performer, curator, engineer, writer, independent scholar, and then I finally became a professor of applied aesthetics and theory of art. A journalist once wrote, regarding my lexicon, that I had had an interesting life, like Jack London. That wasn't entirely true, though...

When I began work on my doctoral dissertation - a long time ago, in 1987 - I opted for the open, plastic, and porous identity of an aesthetician and theorist of art. That decision had serious ramifications for my subsequent life - for 21 years now I have taught aesthetics and theory of art at the Faculty of Music in Belgrade, the Faculty of Media and Communications, and, as a visiting scholar, at various formal and informal schools in Serbia, Slovenia, Croatia,

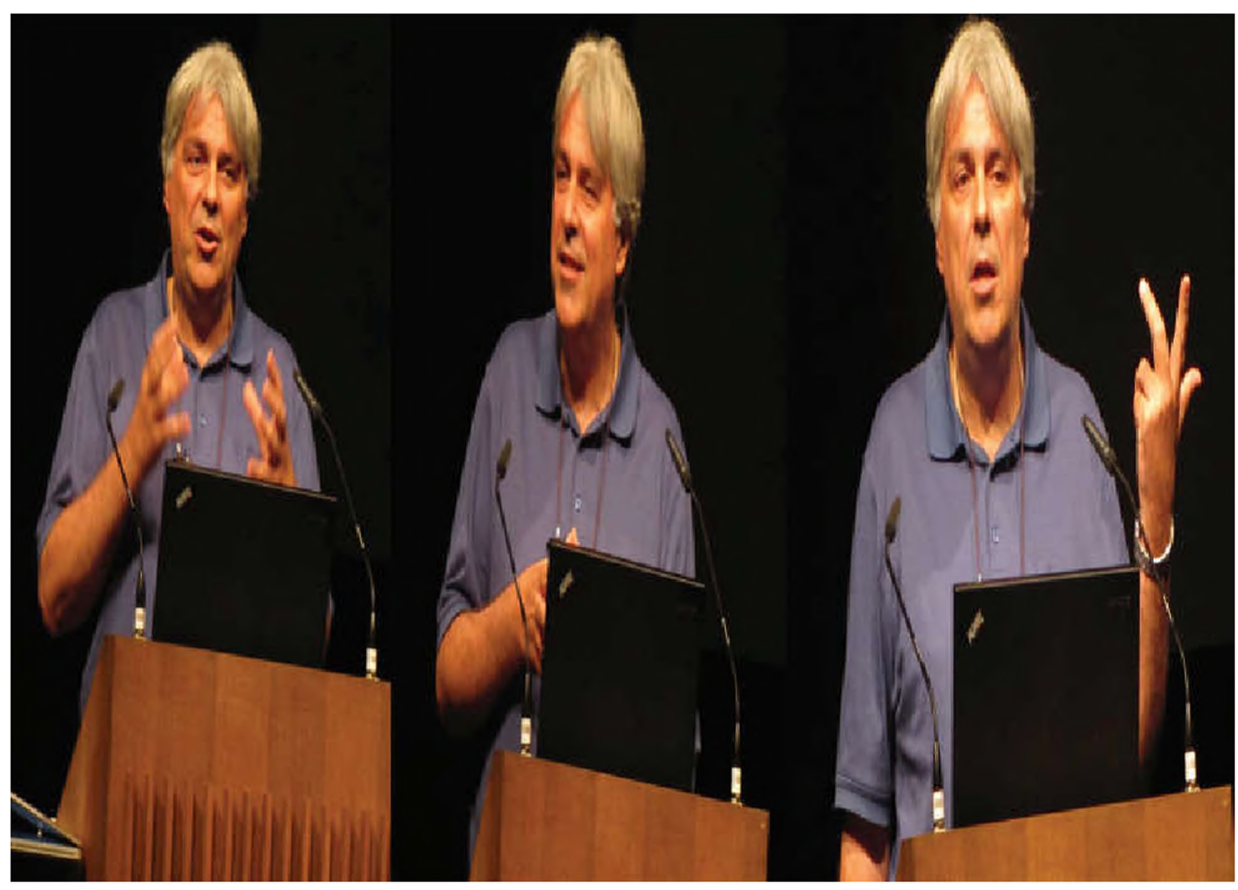


Erjavec, A.: An Interview with Prof. Dr. Miško Šuvaković

Bosnia, Macedonia, the United States, England, the Netherlands, Finland, Austria, Romania, Poland, Turkey, China, Korea, Armenia, Belarus, Russia, etc. Besides the Faculty of Music in Belgrade, my longest affiliations in teaching were with Interdisciplinary Studies at the University of Arts in Belgrade (20012015), the Faculty of Architecture in Belgrade, the Faculty of Humanistic Studies in Koper (Capodistria), and SCCA in Ljubljana.

But one should certainly explain a statement such as "I am an aesthetician" or "I am a theorist of art". All statements beginning with "I am" are at the same time binding and demonstrative in terms of identifying. In other words, "I am an aesthetician" inasmuch as aesthetics as a discipline has been able to transform itself from a closed philosophical discipline written "by philosophers for other philosophers" into a mobile, accelerated, and nomadic practice of exploring art; relations among the arts; relations between art, culture, and society and, first and foremost, the complex field of dispositives and discourses whereby art is performed "through" the world. Therefore, for me, aesthetics is not only "the study of the sensuous/of sensuality", but also a kind of relational analytical and critical practice whereby the sensuous and conceptual are confronted in relation to the discourses and dispositives of historical intervals and geographical locations in relation to my body in its fragmentary individuality, demonstrated strength and solidity, vulnerability and concern, mortality and a merry sort of optimistic playfulness. Aesthetics deals with the complexity of the relationship between the sensuous and the conceptual, i.e. the dispositive and the discursive in relation to fragmentary or totalizing forms of life. That is the concept of aesthetics that I champion!

Then... I have also addressed and still deal with $20^{\text {th }}$ - and $21^{\text {st }}$-century art and theory. Contemporaneity is an important theme/phenomenon in my research in aesthetics.

If we're talking about the arts, then we're talking about interdisciplinary and transdisciplinary relations between the visual arts, performing arts, and new media arts. For instance, I study music in relations between performing and new media practices. Interdisciplinary here means moving from one discipline toward other disciplines. Transdisciplinary means moving nomadically across various disciplines and their continual transformations. In formal terms, what matters is the relation between vector and trajectory. Interdisciplinarity has a vector orientation, transdisciplinarity features a nomadic contingent type of moving across multiple trajectories at once. Roaming turns into a diagrammatic accumulation of data, i.e. into drawing visible and invisible maps of knowledge.

Still, if I should be more specific, most of my work has been orientated towards exploring the conditions and circumstances of transcending the fine arts 
towards "new artistic practices" and, for sure, towards exploring relations between music and experimental work, production, and acting, which has led me towards various ideas relating to conceptually orientated performance art. International conceptual art and American experimental art and music formed the initial matrices of my interests, perhaps desires as well. A part of my work was linked to artistic production in the context of analytical conceptual art. From 1975 to 1980 , I collaborated with Grupa 143 (Group 143), an art and theory group, as well as with Zajednica za istraživanje prostora (Community for Exploring Space), from 1983 to 1989. Later, I also worked with Teorija koja hoda / Walking Theory, a theory and performing arts platform (since 2000). Today, I write and participate in the work of a global association called Provisional Salta Ensemble, probably since 2008 .

I like to write about practices and artists who are my contemporaries. I have written monographs about a number of artists - Gabrijel Stupica, Neša Paripović, Slavko Bogdanović, Koloman Novak, the groups KôD and ( $\exists$, Dragomir Ugren, Vlado Martek, Zlatko Kopljar, Vlasta Delimar, Dušan Kirbiš, the group OHO, Tadej Pogačar, Živko Grozdanić... I have written aesthetic interpretations of composers including John Cage, Philip Glass, Srđan Hofman, the group Opus 4, Jasna Veličković...

I am not interested in theory qua theory, but in ways how to introduce theory to life and theorizing life in relation to art, culture, and society.

During the early 1970s, I also discovered Bauhaus, with Paul Klee's pedagogical sketches, Malevich's analysis of the "additional element" and Duchamp's broadening of the concept of art into the domain of appropriation. At the SKC $^{1}$ there was an excellent bookshop with new books that were reaching us through the Iron Curtain. Around that time I sold my collection of comic books that I had begun collecting as a child, to Goran Đorđević, a colleague and acquaintance from the SKC. I used the proceeds to purchase a book of essays by Malevich and a book about performance art. Biljana Tomic introduced me to the work of Art \& Language and American conceptual art and theory. During that time - I think that was already the late 1980s - I went to Stefan Morawski's lectures at the SKC. Morawski demonstrated how we in the East could think Western philosophy, aesthetics, and art. He had an affective effect. At Kolarac, I attended lectures by Danko Grlić. This was not the type of theory I sought. I was reading various things: Benjamin, Barthes, Quine, Eco, Adorno, Austin, Foucault, Lacan, Lotman. But everywhere, the basis was language theory. I was interested in language - the functioning of art between the verbal and the

1 Student Cultural Centre, Belgrade - Translator's note. 
Erjavec, A.: An Interview with Prof. Dr. Miško Šuvaković

non-verbal - between knowledge and sensory demonstrability, as well as how sensory demonstrability might be translated into linguistically mediated knowledge.

I was involved in three projects to set up alternative schools: Seminar, with Group 143 at the SKC in 1978; Zajednička škola o prostoru-Seminar i izložba (Collective School of Space - Seminar and Exhibition) at the Salon of the Museum of Contemporary Art in 1981; and Seminar - Primeri tekstualne prakse $u$ vizuelnim umetnostima dvadesetog veka - čitanje tekstova (Seminar - Examples of Textual Practice in $20^{\text {th }}$-century Visual Arts - Public Readings) at the SKC from 1985 to 1988 . In that seminar, we organized, for the first time in Belgrade, public readings of texts by Lacan and Deleuze and Guattari. At the seminar I got in touch with the Slovenian philosopher Matjaž Potrč and Croatian philosopher Nenad Miščević. At that time, they were moving away from post-structuralism towards analytical philosophy, while I was moving in the opposite direction, from analytical philosophy toward post-structuralism.

It was only in the 1980s that I began moving towards aesthetics qua "aesthetic theory" and then only "theory". Meeting Prof. Milan Damnjanović in 1983 was also important. I met Aleš Erjavec and Lev Kreft at a conference on the avant-garde, held in Ljubljana in 1986. At that time, I got to know and read Heinz Paetzold - the German aesthetician and, at the time, still a radically and critically orientated thinker. With Erjavec and Kreft I established a collaboration that is still ongoing today. This collaboration has marked and demonstrated the fundamental transformation of aesthetics into theory. At Ljubljana airport, returning from a conference entitled Gesamtkunstwerk. Celostna umetnina (1988) organized by the Slovenian Society of Aesthetics, I met Mira Veselinović Hofman and Marija Bergamo. That was the beginning of a collaboration and friendship of many years, which resulted in our working together at the Musicology Department of the Faculty of Music in Belgrade from 1996 to the present.

I submitted my doctoral dissertation proposal at the Faculty of Fine Arts in Belgrade in 1987, under the title of Teorija umetnosti $i$ analitička filozofija (Theory of Art and Analytical Philosophy). I defended it in 1993 before a committee, comprising Dr. Milan Damnjanović, Dr. Ljubomir Gligorijević, and Dr. Ješa Denegri. Whilst writing, I was employed at the Lola Institute in Belgrade.

Why does aesthetics play such a central role in your reflections upon art, the world and society?

I may say that I was lucky in my theoretical work - my public life in theory/art began at a time when a major paradigm of Western aesthetics was coming to an end - whether truly or only apparently - by abandoning the 
meta-language of philosophy (Heidegger, Wittgenstein, Marcuse) and entering into concrete re-examinations, i.e. individual theories and theorizations:

- Adorno: It is self-evident that nothing concerning art is self-evident anymore, not its inner life, not its relation to the world, not even its right to exist. (1969)

- Weitz: The primary task of aesthetics is not to seek a theory but to elucidate the concept of art. Specifically, it is to describe the conditions under which we employ the concept correctly. (1956)

- De Man: ... what is it about literary theory that is so threatening that it provokes such strong resistance and attacks? It upsets rooted ideologies by revealing the mechanics of their workings; it goes against a powerful philosophical tradition of which aesthetics is a prominent part; it upsets the established canon of literary works and blurs the borderlines between literary and non-literary discourse. (1982)

- Derrida: ... when and how does an inscription become literature and what takes place when it does? ... What takes place between philosophy and literature, science and literature, politics and literature, theology and literature, psychoanalysis and literature? (1983)

- Hall: I am not interested in Theory, I am interested in going on theorizing. (1985)

Etc., etc., etc., etc., etc., etc., etc.

All of the above signifies different aspects of the crisis of philosophical aesthetics and points to various directions in the abandoning, quitting, or rejection of aesthetics in favour of theory, writing, theorizing, or acting. In his history of Tel Quel magazine, Patrick French discussed this period - from 1960 to 1982 - as "the time of theory".

One may say that the interstices between cultural theory and the completion of philosophical aesthetics also saw a "reset of aesthetics" in some authors in the 1980s and later, in the '90s. This fresh re-examination of aesthetics as a discipline started in multiple directions: examining the anaesthetic (Welsch), redefining aesthetics as cultural theory or philosophy of culture (Paetzold), deriving aesthetics as the theory of the avant-gardes (Kreft, Erjavec, in a way myself as well), converting aesthetics into the politics of the aesthetic (Rancière), etc.

Would it be correct to say that in your "theory" aesthetics is equally "philosophy": that you have turned the traditional relation wherein aesthetics was a discipline of philosophy into a relation in which aesthetics and philosophy are fused into a single theoretical discourse? 
Erjavec, A.: An Interview with Prof. Dr. Miško Šuvaković

I set out from the anti-philosophical heritage of modernism and late modernism. I was fascinated by those authors who moved beyond the safety of jargon and, to be sure, the infrastructural context of philosophy as a meta-language about all other languages. Certain names were important in this regard. Walter Benjamin confronted deep philosophical meditation on the universal with literary production, i.e. with producing essays on cultural actuality. Ludwig Wittgenstein established an auto-therapeutic relation between himself as a thinker and philosophy as a public language in crisis. Jacques Lacan acted outside of philosophy, posing fundamental philosophical questions about the limits of subjectivation and de-subjectivation - the remains of the subject. Lacan showed that one could produce philosophy beyond the traditional contexts of philosophizing. Wittgenstein and Lacan, in a most dramatic fashion - in almost epic dimensions - posited the potentiality of anti-philosophy. To be sure, Lyotard's late critique of the meta-language of modernity has a similar potential of critiquing the closed quality of philosophical "language games". Theory produced by authors gathered around the Tel Quel magazine set up the framework for theoretical-textual research - they established theory as a new inter-textual type of research. The American writer Kathy Acker worked between prose and theory in the domain of poly-genre writing: a text exists by virtue of absorbing other texts. Etc., etc.

To be sure, a major part in my story was played by Theodor Adorno's aesthetic theory, who, while certainly not an anti-philosopher, formulated the notion of aesthetics as a "negative" theory of contemporary (in Adorno's time) art, culture, and society. I learned about negativity slowly and it took me a long time. I was confronted with the contradictions and contingencies that ruled and still rule between the politics of dialectics and the politics of difference.

An obvious example of the "plastic" fusion of aesthetics and philosophy to form the discourse of theoretical work is my book Estetika muzike. Modeli, metode $i$ epistemologije o/u modernoj $i$ savremenoj muzici $i$ umetnostima (Aesthetics of Music: Models, Methods, and Epistemologies about/in Modern and Contemporary Music and the Arts, 2016). This complex writing is a theoretical work dedicated to transdisciplinary studies of music as well as to relations between music and the other arts in terms of discourse and dispositive. Conceived in those terms, Aesthetics of Music belongs in that domain of research classified as applied aesthetics and comparative art theory. Also, these explorations, analyses, and discussions may be understood as "music aesthetics after Adorno". The book is composed in two related but significantly different segments.

In other words, the first part, “Outcome/Outlet: muzika između pojedinačnog i opšteg znanja" (Outcome/Outlet: Music between Individual and General 
Knowledge) is a self-critical and anti-systemic analysis of studying interpretative relations between music, art, and humanist and social theoretical discourses in the open domain of applied music aesthetics. There I set up an utterly personal, almost confessional speech on music and the ways I discovered "the powers" of music that resisted and/or supported my understanding of music and the complexity of culture and society. It comprises problem discussions and interpretations of music, the musical work, and the world/worlds of music. These interpretations and discussions of music are derived from the theory of "discursive analysis" and the "dispositive" (apparatus), borrowed from Michel Foucault's epistemology and later elaborated by Giorgio Agamben. I was also led by a negative position, as a basis for initiating revisionist viewpoints regarding music. Why revisionism? Because - and this is my almost unquestionable belief - every age and every geographical location included in individual or collective subjectivations should enable a different and thereby also new insights in music, in my case: in thinking and speaking about music.

The second part, "Prilozi: rekonstrukcije teorijskih platformi moderne i savremene estetike muzike" (Appendices: Reconstructions of Theoretical Platforms of Modern and Contemporary Music Aesthetics), is a systemic and critical general analysis and discussion, as well as the reprocessing of important modern, postmodern, and contemporary theoretical platforms in aesthetics, the philosophy of music, meta-musicology, sociology, psychoanalysis, and anthropology of music. Its object of research is the analysis and discussion of "read" and "heard" knowledge of music and from music. Respectively, individual chapters address questions regarding the ontology of music, phenomenology of music, institutional theory of music, Wittgensteinian conceptual analysis, the semiology of music, discursive analysis of music, deconstruction of music, and political theory of music.

The politicality of music - or, to quote this badly translated English phrase, music through politics - suggests that music is not a timeless practice, invariantly realized in order to be invariantly listened to, heard, and presented in dispositives of feelings and the mind, i.e. the listener's body. Music is always part of a specific community and the way individuals in that community and that community as a whole posit themselves as opposed to other communities and establish themselves in the world and its "world image". I am interested in the image of the world in which Beethoven changed the dedication of his work and crossed out Napoleon Bonaparte, I am interested in the image of the world in which Erik Satie composed his Gymnopédies and John Cage composed his 4'33". Music is a social practice, because through music a community becomes a community and manifests itself as such to itself and to others. Furthermore, that music is a social practice means that it emerges, that it is performed, ex- 
Erjavec, A.: An Interview with Prof. Dr. Miško Šuvaković

changed, and received, inevitably, within institutions based on very, very complex rules, customs, approaches, and conditions of expressing, identifying, and using it as a social tool of seduction, warfare, enjoyment, communication, hatred, manifesting power, representing despair, manifesting indifference, showing love, as well as celebrating reason and surrendering to madness, and constructing aesthetic idealities as the basis of the indisputable canons that I sought to re-examine. Whenever I'm listening to music of whatever kind, I hear these words by Barthes echoing in my ears: "The body passes into music without any relay but the signifier. This passage - this transgression - makes music a madness: not only Schumann's music, but all music" (Rasch).

When you/I write a book whose title almost arrogantly contains the threeword phrase "aesthetics of music" without a mediating word, such as new, i.e. aesthetics of new music, or contemporary, i.e. aesthetics of contemporary music, or experimental, i.e. aesthetics of experimental music, that is, if you do not use phrases such as "new aesthetics of music", "contemporary aesthetics of music" or "experimental aesthetics of music", or "aesthetics of classical music", then you find yourself in the serious predicament of entering an obliging sort of universality from the individuality of your own theories. I accepted that risk, aware of its benefits - I could simultaneously write about Liszt, Gould, and Tudor, or Beethoven and Stockhausen, Schumann and Zorn, Hendrix and Mozart, as well as losses - opening a Pandora's Box of mysterious and unfathomable complexity, whose phenomenal complexity might engulf me like an avalanche in the far-off Alps, where I would gladly stage performing/ listening to/watching Wagnerian opera if I possessed any power in the real world.

But what can we do with music there? Am I entitled to music? And how may I bring to reason and to speech that which I consider myself entitled to?

The book Aesthetics of Music is open to art music in general, but its core is music of a new sound, which is part of musical art and occasionally enters or appears in other arts as well.

The epistemology of music is something to which I am obsessively attracted.

Do you understand aesthetics mainly as a philosophy of art, as a theory of cognition, or as something else?

I am interested in aesthetics in three ways.

Firstly, I am interested in it as a theory of the arts and, more importantly, as a theory of relations between different arts. This concerns the domains of interdisciplinarity and transdisciplinarity. 
Secondly, I am interested in it as a theory of the relationship between the sensuous and the conceptual and more so in an epistemological than a cognitive sense. I am interested in knowing about art as much as I am interested in art itself. That is why the models of discourse and dispositive are important. The sort of aesthetics that I explore, write, and teach is epistemologically orientated.

Finally, thirdly, I am interested in it as the obligation to confront art in bodily and behavioural terms - and not just works of art, but also its institutions, cultural mediators, in a word: the worlds of art.

When one speaks of art and knowledge, one means not only the mastery of the skill of creating/performing a work of art or knowing about works of art, but also knowing the reasons for art in a given time, space, human situation, and, indeed, form of life. Furthermore, speaking of the reason is not an effect of deciphering art, but the multiplicity of interpretations, functions, statuses, and priorities of art that form layers around the artwork, what Artur C. Danto called "the artworld".

You are the author of 52 books, with their topics ranging from Serbian fine arts to philosophy of music. Does that mean that you wish to develop theoretical reflection upon the main artistic genres as well as upon the main aesthetic issues of our time?

I am interested in contemporary art and contemporary theory (aesthetics, philosophy, humanistic studies, cultural theories, etc.). Contemporaneity is an "elastic" concept - from the immediate present to the most recent past, but one could also extend the concept of contemporaneity to artistic or theoretical practices in modernism and postmodernism's transformations into present contemporaneity. In terms of chronology, I am interested in $20^{\text {th }}$ - and $21^{\text {st }}$-century artistic and theoretical practices.

No, it is not my intention to produce an encyclopaedia, i.e. a classifying ordering of artistic and theoretical disciplines, i.e. genres in contemporaneity. I am interested in observing the relations between various disciplines and genres - and in confronting them in a relational field or map of indices. In the past, the concepts of disciplines and genres did not overlap. Disciplines comprised related media or sensory practices, while genres comprised related thematizations. Today, in the age of post-media arts (performance, new media, participatory practices, found art, etc.) the concepts of discipline and genre are become increasingly close - that is, similar. For instance, with a digital computer we can simulate various artistic expressions and thematic representations. Performance is no longer an individual discipline, but signifies the flexibility/ plasticity of the transformation of disciplines. 
Erjavec, A.: An Interview with Prof. Dr. Miško Šuvaković

I am interested in seeing how an idea emerges, transforms, or disappears, that is, how it is appropriated, mutated, and differentiated in various arts. For instance, I am interested in seeing how the notion of a void emerges in painting (Yves Klein), environmental art (Zoran Belić W.), the theatre (Samuel Beckett), music (John Cage), or film (Stan Brakhage). I have devoted so much of my time to the avant-gardes and neo-avant-gardes precisely because there, the borders between individual disciplines and genres are unstable/mutable and mobile. The instability/mutability of those borders was an effect of experimentation: of searching for new means, procedures, protocols, attractions, affects, and concepts. Even today, I am still fascinated by the new.

My work was never exclusively associated with contemporary Serbian or Yugoslav art. When I was beginning my work in aesthetics and art theory, I was chiefly attracted by American (Fluxus, minimalism, conceptual art), British (conceptual art), and French art (fundamental and political painting). Only later did I begin addressing, in the domain of the visual arts, Yugoslav, Serbian, Croatian, and Slovenian art. Working on Impossible Histories, a collection of texts I edited with Dubravka Đurić, and Istorije umetnosti $u$ Srbiji: XX vek (Histories of Art in Serbia: The $20^{\text {th }}$ Century), I began working on systemic and anti-systemic art and theory practice in bourgeois, socialist, and societies in transition. This suggests that I am primarily interested in issues related to the material contexts of artistic practices and their reformulations in time and space, in relation to cultural knowledge.

For example, I spent a long time working on a theory of the avant-gardes and neo-avant-gardes. The relationship of these two historical formations of new art was treated linearly and often, for instance in Peter Bürger's work, the neo-avant-garde was posited as a "second-hand" avant-garde. My view, which I would strongly defend, is that the status of the avant-garde and neo-avant-garde is determined by the positioning of critical, experimental, and artistic practices with regard to dominant modernism. If that is so, then the historical avantgardes were the vanguard of modernism and its canonical formats, whereas the neo-avant-garde was either the realization of the utopias of the avant-gardes in the new technological conditions of the Cold War world, or an immanent critique of the canon of high modernism and its autonomous aestheticism.

Your analyses of art as well as your theory in general are very often related to politics. Would you agree if I were to say that this preoccupation with politics was caused by your life - our lives - in a socialist country, in a small culture, and on this "powder-keg" called the Balkans? 
I might say, similarly to most of us who got a "good" taste of the differences, antagonisms, and conflicts of the $20^{\text {th }}$ century, that my life unfolded and is still unfolding between the public and the private - the presentable and the un-presentable - in a permanent state of emergency: the communist revolution, the Cold War, the self-managed liberation from bureaucratic communism, the first economic crises of socialism, the crisis of real-socialism, the transitional original accumulation of capital, nationalist hysterical-paranoid persecution, and the realization of global neo-liberalism and its crises that are visible today. This is something that one cannot transcend, whether by means of good intentions or a cheerful disposition, it is something that keeps occurring in my life, with consequences. Ontological pessimism is inevitable. That is why both in my written work and lectures I have resorted to the only tools that modern and contemporary humans managed to build in their resistance to a permanent state of emergency: a minimum of rationality, a critical outlook on reality, and a radical analysis of whatever happens to be one's daily occupation; for me, that would be art and theory.

Wittgenstein wrote that his philosophical task is to show the fly the way out of the fly-bottle. I would like to get out of the fly-bottle - the imposed image of the world - like that fly, the one Wittgenstein sought to teach in his Philosophical Investigations, but I am afraid that once I get out of my fly-bottle or my world, I might find myself in another one, a bigger or smaller fly-bottle, which would again be mine and for me, a limited space for us and for other lives, a domain of repression and pressure. That is why following Wittgenstein, Louis Althusser became important to me. Wittgenstein showed us the way out of the fly-bottle in which we were trapped and Althusser taught us how to recognize that new bottle, as the ideological apparatus that intervenes in my or our perception of reality.

What is the direction of that minimum of rationality, critical approach, and radical analysis? Well, surely that which is caught up - metaphysically and existentially - between un-presentable-silent life and life that is presentable and effable through art and theory. What is "it" that is trapped? Perhaps it may be recognized, i.e. named as a "form of life". In other words, it concerns a state of emergency in which "forms of life" take place in all the evasions and approximations within the events of contemporaneity. And art is a sort of symptom whether we're talking about the archives of Walid Raad, Alfredo Jaar's media critique, the simulacra or apparitions of totalitarianism of Laibach, or Heiner Goebbels's empty space of "shadows of Hamlet machines".

My interest in political theory is certainly indebted to my friendship and collaboration with you and Lev Kreft. 
Erjavec, A.: An Interview with Prof. Dr. Miško Šuvaković

In 2012 you published the book Umetnost i politika that has more than 600 pages. Once again you wrote about politics. How would you define this "politics"? Is this la politique in the sense of Jacques Rancière, Claude Lefort, or Chantal Mouffe, or do you interpret it in some other way?

The book Art and Politics was an attempt to confront immediate contemporary local and global art and politics. The book was written from the perspective of an "Eastern European" deriving a global view of contemporary regimes of politics and art. I was interested to see how a local position and particularized viewpoint might wish to realize a universal critical discourse. The discussions gathered in that book were aimed at identifying the time after post-modernity and its "liberal hope" for a conflict-free world, multiculturalism, and the legitimacy of division [raskol]. In other words, I was interested in the theory of politics after Jean-François Lyotard and his fascination with possible/impossible pluralisms.

In my work, I have used three notions of politics! The basic, traditional notion: politics is the performance of sociality. This certainly involves discontinuous lines of thinking politics from Aristotle to Hannah Arendt and perhaps some of today's contemporary philosophers. Then there is the derived modern notion of politics as the technology of power or resistance to the technologies of power. This certainly concerns the question how to use Foucault's philosophy of structural power. And - Chantal Mouffe's contemporary notion: politics as the aggregate of practices and institutions whereby a social order or relation is realized, and the political as the multiplicity of antagonisms that are constitutive of human society.

I was interested to see why politics in the opening decade of the new century became such an important point of reference in art. And not just a point of reference, but also the dispositive whereby it is performed in public spaces in parallel to the world of art. Art then, unlike in modernism and the avant-gardes, was not just an autonomous practice that had entered into the field of engagement, i.e. politicization, but was forged "from" the matter of the political, above all from material events, i.e. antagonisms in the everyday contemporary world. If we were to put this in terms of a statement, one might say that politics became the "medium of art". But wasn't that, in a way, also the subject of two books that you conceived and I participated in as a writer: Postmodernism and the Postsocialist Condition: Politicised Art under Late Socialism (2003) and Aesthetic Revolutions and Twentieth-century Avant-garde Movements (2015)!?

Who would the other theorists be with whose theory or philosophy you identify? 
Reading has always been an integral part of my life. I read various authors and their impact was certainly important. Some of them were part of my education, in which I sometimes recognized myself and at other times did not: from Augustine via Voltaire and Kant to Marx, Freud, and Nietzsche. Via the Tel Quel magazine I came upon this important idea/strategy: that three $19^{\text {th }}$-century thinkers made a key impact on $20^{\text {th }}$-century philosophy, aesthetics, and theory: Marx with his class struggle, Freud with the unconscious, and Nietzsche with his failure to produce a theoretical system.

I was truly influenced by the philosophy, or, as some today write, the antiphilosophy of Ludwig Wittgenstein. The philosopher Wittgenstein, in relation to the artist Marcel Duchamp, constitutes the truly important initial platform of my "theorizing" on the arts, including music. With Wittgenstein began my interest in anti-philosophy or the elaboration of various critical regimes within art theory and aesthetics. I searched for discourses of scepticism: from Wittgenstein to Lacan, from Lacan to Adorno and Benjamin. This involved no chronological but an epistemological ordering of knowledge. And yes, indeed, likewise important was Arthur C. Danto's aesthetic theory, above all his notion of the "artword"! But more than Danto, concerning art, I was influenced by artists" writings, above all by Art \& Language and Charles Harrison, as well as Victor Burgin and American artists Joseph Kosuth and John Cage and Kathy Acker.

Regarding my work on Diskurzivna analiza (Discursive Analysis) and Estetika muzike, especially important were Michel Foucault's models of discourse and dispositive. However, I was never a Foucaultian, but rather a wild nomad who stole some of his ideas and turned them into my own apparatuses for uses that significantly diverged from his real intentions and explorations. In other words, I applied the concepts of "discourse" and "dispositive" to the arts and, especially, to music and not his topics: the prison, the school, the hospital, the mental asylum, police, army, or modern administration. Foucault was truly useful for me, though I cannot identify with his multifaceted and expansive work. My approach to his work was to survey it, appropriate from it whatever I needed, and transform it.

I am certainly well-acquainted with Slovenian theory, philosophy, and aesthetics. I have also written two books on Slovene [slovenska] philosophy, aesthetics, theory, and art: Anatomija angelova (2001) and Slovenska filozofija dan pozneje (2012). Yes, not only the discourse but also the "atmosphere" prevailing in theory during the $1970 \mathrm{~s}$, ' $80 \mathrm{~s}$, and early '90s was quite stimulating. The first "Slovenian author" I heard and read was Braco Rotar from the time of the Scheferian and Marinian semiology of painting. His lecture on the semiology of draperies was surprising and revealing, although draperies in painting did not 
Erjavec, A.: An Interview with Prof. Dr. Miško Šuvaković

interest me at all. Certainly, without Dušan Pirjevec's analyses and discussions, I could never understand Heidegger's discourse. Then, I read the magazine Problemi. Razprave, which was a stimulating journal in the 1970 s and early '80s. It featured a mix of anti-psychiatry, Lacanianism, Althusserians, as well as analytical philosophy. Texts by Močnik, Žižek, Dolar, and early Potrč were certainly influential as well. For me perhaps the most important was that early Althusserian-Lacanian period in their work. I closely studied Jure Mikuž's book Podoba roke. That book included studies that established psychoanalysis as an interpretative platform for examining Slovene national painting.

When it comes to music aestheticians and musicologists, i.e. writers on music - I read many of them. Several names I would certainly single out would be Adorno, Stephen Davies, Focht, Subotnik, Nyman, and maybe, maybe - as always - John Cage, although I would not forget Glenn Gould or Stockhausen either. I would also add there someone who was neither an aesthetician nor a musicologists nor a musician, but certainly wrote important things about music and the type of society confronting me: Thomas Bernhard, with his novels The Loser and Wittgenstein's Nephew, as well as Thomas Mann with Doctor Faustus - the final instance in the $19^{\text {th }}$ century's understanding of music in its demonic sublimity. In other words, if I were to identify with other theorists, that would not mean identifying with individuals only, but rather with situations, times, and places where emancipatory practices took place: the flow of concepts and desires for a new type of expression in theoretical work. Whereas Foucault wrote that society must be defended, I would write that one should defend the right to complexity and ambiguity.

In your opinion who are the contemporary maîtres penseurs (master-thinkers)?

Whenever I read Kant or Hegel, I wondered about those others who were left languishing in the shadow of their work. I wondered how the vanishing and canonizing of knowledge unfolded over time. Today, two centuries after them - the world has really changed. We encounter new authors and their interpretations every day. So really I would rather talk of kaleidoscope thinkers than master thinkers. There are too many theoretical parameters at stake, coming from the First, Second, and Third World, in order to hide them all behind a great teacher. Today, the image of master knowledge is kaleidoscopic, or, in computer-science jargon, hyper-textual. Thus, today we have more than one Hegel, Kant, Bach, Cage, or Duchamp... When I say that we have more than one, I mean that there is differentiation not only in terms of genre identifications, but also racial, gender, generational, political, aesthetical, and other sorts of identification. 
In 2019 Belgrade will host the $21^{\text {st }}$ congress of the International Association for Aesthetics. You are the chief organizer of this event that takes place every three years in a different part of the world, and is the biggest gathering of people with an interest in aesthetics and related realms. The 2019 congress is titled "Possible Worlds of Contemporary Aesthetics - Aesthetics between History, Geography, and Media". Can you please elaborate on this title?

Preparing the $21^{\text {st }}$ congress of the International Association for Aesthetics in 2019 is a great challenge. Prof. Milan Damnjanović organized the ninth congress in Dubrovnik in 1980. That was the initial impulse for the establishment of aesthetics societies in the second Yugoslavia. I think the $21^{\text {st }}$ congress will be a unique opportunity for aesthetics in Serbia and this part of the world, and even for European aesthetics in general. Aesthetics back in Europe!? We are hoping for new movements in the field of studying aesthetics and theories of art and culture, as well as for a large number of participants. The congress is organized by the Society for Aesthetics of Architecture and Visual Arts of Serbia, which is affiliated with the Faculty of Architecture in Belgrade. Prof. Vladimir Mako and I started this initiative with younger colleagues from the Society. The $21^{\text {st }}$ congress of aesthetics may truly be of historical significance for our cultural space. A great opportunity.

The title of the congress, "Possible Worlds of Contemporary Aesthetics Aesthetics between History, Geography, and the Media", points to the view that in today's world there is more than one "world image of aesthetics", unlike, for instance, at the founding congress, which was initiated by German aesthetician Max Dessoir, in Berlin in 1913. In professional and cultural terms, aesthetics is today a hybrid domain involving various traditions, disciplines, viewpoints, and their geographic histories. These are "platforms" that rely on the tradition of Western aesthetics, on various national strands of aesthetics, as well as on continental/intercontinental aesthetic projects: Mediterranean aesthetics, European aesthetics, Asian aesthetics, Euro-Asian aesthetics, African aesthetics, American aesthetics, South American aesthetics, aesthetics from Australia and New Zealand, etc... The congresses held in Brazil, Japan, China, and Korea opened this intercontinental dialogue. The $21^{\text {st }}$ congress in Belgrade should reposition the European perspective, but in relation to its international and global dialogue partners. Complexity and complicity are my motto regarding my involvement with this conference. In disciplinary terms, contemporary aesthetics, like a sort of intelligibility umbrella, covers philosophical aesthetics, various kinds of applied aesthetics, the aesthetics of architecture, design, new/digital media, music, film, the visual arts, theatre, performance, as well as various kinds of cultural 
Erjavec, A.: An Interview with Prof. Dr. Miško Šuvaković

aesthetics: the aesthetics of the everyday, of mass culture, popular culture, feminism and gender, that is, of various forms of life.

The congress title, "Possible Worlds of Contemporary Aesthetics - Aesthetics between History, Geography, and Media", points to various strands in contemporary aesthetics and their dispositives, as well as to three important spaces where the aesthetic and aesthetics [estetsko $i$ esteticko] take place: the space of history (the politics of time), the space of geography (the politics of planetary topoi), and the space of media (the politics of networks and virtual systems). The purpose thereby is to achieve a high level of openness to global dialogue.

What is to be the theme of your next book?

The title of my next book will be Neo-aesthetic Theory: Complexity and Complicity Must Be Defended, to be published by the Austrian publishing house Hollitzer Verlag in April 2017. It is a collection of discussions that I wrote on various occasions and that are now grouped in a certain interpretative schema, comprising texts on political art theory; the arts during the age of socialism, the Cold War, and post-socialism; the aesthetics of music; the aesthetics of architecture; performance art; post-media art; and experimental, so-called poly-genre theory. 